\title{
Pszichoterápia a szülészeten: lehetőségek alacsony intenzitású kognitív viselkedésterápiás intervenciókra
}

\author{
Zinner-Gérecz Ágnes - Perczel-Forintos Dóra dr. \\ Semmelweis Egyetem, Általános Orvostudományi Kar, Klinikai Pszichológia Tanszék, Budapest
}

\begin{abstract}
A szülés utáni idôszakban megjelenő aggodalmak természetesnek tekinthetők, az anyák jelentős részénél azonban klinikai szintû́ szorongásos megbetegedés alakulhat ki. A postpartum időszakban a szorongásos tünetek gyakori előfordulása ronthatja az anya életminőségét, pszichés állapotát, s ezáltal kedvezőtlen hatást gyakorol az anya-gyermek kapcsolatra, a gyermek mentális fejlódésére, a párkapcsolatra, valamint a családi rendszer egyensúlyára. Kutatási eredmények igazolják, hogy a szorongásos zavar a késóbbiekben megjelenó anyai depresszió elórejelzóje lehet. A nemzetközi irányelvek (NICE) a peri- és postnatalis időszakban jelentkező szorongásos zavarok kezdeti kezelésében az alacsony intenzitású pszichoterápiás módszereket javasolják. Tanulmányunk elsődleges célja, hogy egy esetismertetésen keresztül, kérdőívekkel követve az állapot változását, bemutassuk a szülészet-nőgyógyászat területén alkalmazható, kis intenzitású pszichológiai intervenciók eszköztárát. Az utóbbi a kognitív viselkedésterápia alapmódszereit használja kórházi osztályos, illetve ambuláns keretek között. A pszichoedukációt, normalizálást és átkeretezést, problémafókuszú keresztmetszeti konceptualizálást, szisztematikus deszenzitizálást és problémamegoldó technikákat tartalmazó intervenciók hatására az anya jelentős szenvedést okozó szorongásos panaszai már négy pszichoterápiás találkozást követően csökkentek, az anya képessé vált arra, hogy gyermekét ellássa. A terápia hatékonyságát, a szorongás és a depresszió csökkenését a páciens szubjektív megélésén túlmenően az állapotkövető kérdőívek eredményei is teljesen mértékben alátámasztották. Eredményeink megerősítik, hogy az alacsony intenzitású pszichológiai intervenciók hatékonyan alkalmazhatók a kórházi osztályokon a szorongásos, depressziós panaszok csökkentésében és ezáltal költségkíméló módon a pszichés zavarok megelózésében.
\end{abstract}

Orv Hetil. 2021; 162(44): 1776-1782.

Kulcsszavak: szülészet, postpartum szorongás, alacsony intenzitású kognitív viselkedésterápiás intervenciók, klinikai pszichológia, megelőzés

\section{Psychotherapy in obstetrics: implementing low intensity psychological interventions}

The occurrence of postpartum worries is considered a normative phenomenon, although the threshold of anxiety reaches clinical level and can lead to the development of postpartum anxiety disorder for a significant number of new mothers. Frequent occurrence of anxiety-related symptoms can negatively influence the mother's quality of life, psychological status, the mother-child relationship, the newborn's mental development, the relationship of the couple as well as the balance of the family system as a whole. Studies show that postpartum anxiety disorder can lead to depression later on. International guidelines (NICE) suggest peri- and postnatal anxiety disorders to be treated using low intensity psychological interventions (LIPIs). The aim of this study is to present the different methods of LIPIs used in obstetrics and gynecology through a clinical case study, while monitoring the outcomes in the mothers' psychological status by the use of questionnaires. LIPIs contain the basics of cognitive behavioural therapy used in hospitals in both in- and outpatient care. After only four psychotherapy sessions using psychoeducation, normalizing and reframing, problem-centered cross-sectional conceptualisation, systematic desensitization and problem solving techniques, the mother's severe symptoms of anxiety decreased significantly, enabling her to take proper care of the newborn. The efficacy of the therapy was confirmed thoroughly not only by the subjective experience of the patient, but the results of the questionnaires used to follow the psychological status of the patient. Our results show that LIPIs can be effectively used as a cost-effective method to reduce symptoms of anxiety or depression, and to prevent the development of mental health problems among hospital patients. 
Keywords: obstetrics, postpartum anxiety, low intensity cognitive behavioural interventions, LIPI, clinical psychology, prevention

Zinner-Gérecz Á, Perczel-Forintos D. [Psychotherapy in obstetrics: implementing low intensity psychological interventions]. Orv Hetil. 2021; 162(44): 1776-1782.

(Beérkezett: 2021. március 4.; elfogadva: 2021. április 10.)

\section{Rövidítések}

BDI $=($ Beck Depression Inventory $)$ Beck Depresszió Kérdőív; EMMI = Emberi Erőforrások Minisztériuma; LIPI = (low intensity psychological intervention) alacsony intenzitású pszichológiai intervenció; NICE $=($ National Institute for Health and Clinical Excellence) az Egészség és Klinikai Kiválóság Nemzeti Intézete; RS = Reménytelenség Skála; STAI = (StateTrait Anxiety Inventory) Spielberger Állapot- és Vonásszorongás Kérdőív

A várandósság, valamint a szülés utáni időszak a különböző pszichés zavarok kialakulása szempontjából fokozottan sérülékeny periódus. A szülést követően a hormonális változások mellett az édesanyák számos fizikális és pszichés kihívással találják szembe magukat; ezek közül kiemelten fontos az új szerepükhöz való alkalmazkodás, ezen belül is a gyermekükkel való összehangolódás. A gyermek születése normatív krízisnek tekinthető; olyan életesemény, amely egyedülálló szépsége és örömei mellett az említett stresszorok révén jelentős alkalmazkodást kíván az anyáktól, s kevésbé sikeres kimenet esetén pszichés egyensúlyvesztést idézhet elő [1]. Mindezt sorba véve nem meglepő, hogy ez az időszak veszélyeztetettséget jelent különféle pszichés zavarok kialakulása szempontjából (például szorongás, gyermekágyi depresszió, poszttraumás stressz zavar stb.) [2]. A prae-, peri- és postnatalis időszakhoz társuló komorbid pszichés zavarok felismerésében és a nemzetközi irányelvek alapján történő kezelésében a panaszok megjelenésének korai időszaka rendkívül meghatározó, amikor már alacsony intenzitású intervenciókkal jelentős változás érhető el. Mindez szakpszichológus jelenlétét teszi szükségessé a szülészeti és nőgyógyászati osztályokon, amit hazánkban a 2013-ban elfogadott EMMI-rendelet szabályoz (73/2013. [XII. 2.] EMMI rendelet). Ez könnyen illeszkedik abba a folyamatba, amelyet az elmúlt 30 évben a Magyar Pszichoszomatikus Szülészeti és Nőgyógyászati Társaság elkezdett, és amelynek célkitűzése volt: a biopszichoszociális szemlélet megvalósítása és pszichoprofilaxis alkalmazása a szülészeti és nőgyógyászati ellátásban.

Tanulmányunk fó célja, hogy egy postpartum szorongással küzdő, először szülő édesanya esetén keresztül bemutassuk a szülészet-nőgyógyászati ambuláns és osztályos keretek között, klinikai szakpszichológusok által hatékonyan alkalmazható, alacsony intenzitású kognitív viselkedésterápiás intervenciók eszköztárát.

\section{A szorongásos zavarok előfordulása a peri- és postnatalis időszakban}

A prae-, peri- és postnatalis időszakban jelentős mértékben előfordulhatnak szorongásos zavarok [3]. A legújabb kutatási eredmények szerint a szorongásos rendellenességek gyakorisága a postpartum időszakban kb. 20,7\% [4]. Amennyiben figyelembe vesszük a szubklinikai szorongásos tüneteket, akkor ez az arány a korai postpartum időszakban 17-22\%, a késői postpartum időszakban $15-33 \%$ is lehet $[5,6]$. Megjelenésüket számos tényező befolyásolja, például a terhesség időszakában jelentkező esetleges megterhelő, stresszes életesemények [6], a szociális támogatás alacsony szintje [7], korábbi múvi terhességmegszakítás vagy a nem kívánt terhesség [8], a szülés módja (természetes vagy császár) és a pozitív pszichiátriai anamnézis $[9,10]$.

Mind a peripartum, mind a postpartum időszakban megjelenő szorongásos zavaroknak számos káros hatásuk lehet az anyák mentális egészségére és a szülés kimenetelére. A várandósság időszaka alatt tapasztalt szorongás és stressz kapcsolatban áll a magzati szívhanggal és aktivitással $[11,12]$, a koraszüléssel $[13,14]$, és majd befolyásoló erôvel bír az újszülött viselkedési mintázatára $[15,16]$. A szülés utáni szorongásos zavarok következményei gyakran rontják az anya életminőségét, pszichés jóllétét, emellett kedvezőtlen hatással bírnak az anya-gyermek kapcsolatra, a párkapcsolatra, valamint a családi rendszer egyensúlyára. Kutatások igazolták, hogy a szorongásos zavar a későbbi anyai depresszió előrejelzője is lehet $[17,18]$. A szülés utáni szorongás továbbá kapcsolatban áll a mérsékeltebb anyai önbizalommal, valamint hosszú távú negatív következményekkel járhat a gyermek mentális fejlődését illetően [19-21].

\section{Intervenciók a peri- és postpartum időszakban}

A peri- és postnatalis időszakban jelentkező szorongásos zavarok kezelésére a nemzetközi irányelvek [22] a következőket javasolják:

- enyhe szorongásos állapotokban: kognitív viselkedésterápia alapú önsegítő anyagok, 2-3 hónapon keresztül, személyes, telefonos vagy online formában, maximum 2-3 órán keresztül, 6 alkalommal; 
- mérsékelt vagy középsúlyos szorongásos állapotokban: alacsony intenzitású pszichoterápiás módszerek, s ha ez nem elegendő, akkor magas küszöbü pszichoterápiás intervenciók (például kognitív viselkedésterápia).

\section{Alacsony intenzitású kognitív viselkedésterápiás intervenciók}

Az alacsony intenzitású kognitív viselkedésterápiás intervenciók a standard kognitív viselkedésterápia legújabb, hazánkban kevéssé ismert irányzatához tartoznak. Elsődleges céljuk a mentális egészség megőrzése és a pszichés zavarok prevenciója azáltal, hogy az ellátás már az alapellátásban hozzáférhető enyhe és középsúlyos állapotokban, valamint a szomatikus betegségeket kísérő pszichés nehézségek kezelésében is. Így viszonylag egyszerü, gyors, célzott (minimális) beavatkozással nagy változás érhető el, azaz maximális hatékonyság biztosítható [2325]. Az „alacsony intenzitás” kifejezés arra utal, hogy a pszichoterápiás intervencióhoz nem szükséges pszichiátriára küldeni a beteget, mert már az alapellátásban, illetve a krónikus testi betegségek kezelésekor is elérhető és megvalósítható (például belgyógyászati, bőrgyógyászati, szülészeti, kardiológiai, illetve bármilyen szomatikus osztályon). A LIPI a bizonyítékokon alapuló pszichoterápiák eszköztárát használja fel, elsősorban az enyhe és középsúlyos pszichés zavarok kezelésében. Jellemzői a következők: a rövid kérdőíves állapotfelmérés és utánkövetés, gyors és a páciens egyéni szükségleteinek megfelelően alakított (rugalmas) intervenciók, kisebb ülésszám, a terápiás alkalmak rövidsége, így jól illeszkedik a szomatikus osztályos kezelésekhez is [26]. A terápiás kontaktórák száma a standard kognitív viselkedésterápiához képest kevesebb (max. 6-8 ülés), az egyes találkozások időtartama is rövid (30-35 perc). A LIPI által alkalmazott technikák problémaorientáltak és jól strukturáltak, akár ágy mellett is rugalmasan kivitelezhetők. Az ellátás hozzáférhetőségének kiterjesztésével együtt, a személyes találkozások mellett az e-mailes és telefonalapú kapcsolattartásra, önsegítő anyagok (könyvek vagy internetalapú technikák) alkalmazására is lehetőséget biztosít [25]. A bemutatott LIPI korlátjának tekinthető, hogy a terápiás kapcsolat felépítésére a legtöbb esetben kevés idő jut. Amennyiben mélyebb diszfunkcionális attitűdök és sémák aktivizálódnak, a későbbiekben a módszer időbeli keretein túlmenően további pszichoterápiás segítségre lehet szükség.

A szülészet-nőgyógyászat sajátossága, hogy a páciensek optimális esetben csak rövid időt töltenek a kórházi osztályon, a gyakran felmerülő szorongásos és hangulati zavarok azonban súlyos és szerteágazó következményekkel járhatnak. A postpartum időszakban a hagyományos pszichoterápia igénybevétele nehezített, amely helyzetekben az alacsony intenzitású kognitív viselkedésterápia alapvetően fontos lehet az esetlegesen kialakuló szorongás, depresszió megelőzésében, illetve mérséklésében.

\section{Esetismertetés}

Eszter (fiktív név) 34 éves, először szülő édesanya, első napos gyerekágyas. A nővérek jelzése alapján kifejezetten sírékony, nehezen mobilizálható, nehézségei vannak a szoptatással. Férjével hat éve él kiegyensúlyozott házasságban; a várandósságot megelőzően informatikusként dolgozott.

Panaszok: Az édesanya arról számolt be, hogy szoptatáskor erős félelmet érez, és arra gondol, hogy „valami nincs rendben velem”, és „valami baj fog történni”. A gondolatokat heves szívdobogás, fulladásérzés és nehézlégzés kíséri, fokozott belső feszültségről számolt be, kifejezetten aggódott a hazamenetel és a szoptatás nehézségei miatt. Kényszergondolatok jelentkeztek, folyamatosan azon ruminált, hogy „ilyen állapotban veszélyes vagyok a gyermekemre nézve”, ,félek, hogy annyira szorongok, hogy kiejtem a kezemböl gyermekem és megsérül, valami baja történik miattam”, és úgy érezte, alkalmatlan a szoptatásra.

Pszichiátriai anamnézis: A várandósságot megelőzően két évvel pánikrohamok miatt farmakoterápiás kezelésben részesült, melyet másfél évvel ezelőtt abbahagyott, amikor a várandósságot tervezte. Szorongásos tüneteit első várandósságának korai (10. héten bekövetkezett) megszakadásához köti; gyermeke a második terhességből született. Családi anamnéziséből kiemelendő, hogy édesanyja kezelt pánikbeteg, nagymamája rekurrens depresszió diagnózisával rendelkezik.

Állapotfelmérés: A pszichodiagnosztikai vizsgálatban a kérdőívek eredményei emelkedett szorongásszintet és mélyebb fekvésű hangulatot jeleztek $(\mathrm{BDI}=18, \mathrm{RS}=9$, STAI-S =60). A pszichés status, a keresztmetszeti kép, a kérdőívek eredményei és az exploráció alapján pánikzavar (F41.00) volt diagnosztizálható.

A pszichoterápiás intervenció elsődleges célja a szorongásos panaszok megértése, normalizálása és mérséklése volt. További célként az fogalmazódott meg, hogy a páciens fokozatosan képes legyen gyermekét szoptatni, az anyai kompetencia érzése fokozódjon.

Alkalmazott intervenciók: A panaszok súlyossága, időtartama és a kórelőzmény fényében feltétlenül indokolt volt a pszichoterápiás ellátás, ezen belül a LIPI mint elsődlegesen választandó terápiás beavatkozás. Az alábbi beavatkozásokat alkalmaztuk:

1. Állapotfelmérés és pszichoedukáció

2. Problémafókuszú keresztmetszeti konceptualizálás normalizálás és átkeretezés

3. Relaxáció és légzéstechnika

4. Szisztematikus deszenzitizálás

5. Problémamegoldó technika alkalmazása

Keretek: Napi 30-45 perces találkozások, összesen 4 alkalommal. Az emittálás után utánkövetés a 2. és a 6. héten. 


\section{A terápia folyamata}

A probléma normalizálásával kezdtük, melynek során kifejeztem az édesanyának megértésemet, és elmondtam neki, hogy ezek a nehézségek mással is előfordulnak: „Elsöszülö édesanyaként többen küzdenek a szoptatás nebézségeivel, kettösségérzéssel, hogy bár ez egy gyönyörü élmény, mégis olykor furcsa, szokatlan testi tapasztalatok kisérik."

Ezután megkezdtük a probléma kognitív elemzését (problémafókuszú konceptualizálás). Átbeszéltük, hogy egy olyan, érzelmileg telített helyzetben, mint a szoptatás, természetes, hogy felnagyítja a félelmeit (katasztrofizál), emiatt felerősödik szorongása s az ezzel együtt járó testi panaszok, jelen esetben fulladásérzés, heves szívverés. Ezeket összefoglalva, vizuálisan megjelenítve (lerajzolva) a beteggel közösen átbeszéltük a gondolat-érzéstesti tünet és viselkedés ördögi körét (1. ábra). Eszter szoptatáshoz kötődő negatív, automatikus gondolatai könnyen hozzáférhetők voltak, felismerte azok túlzó (katasztrofizáló) voltát, de nem tudott rajtuk felülkerekedni.

Az explorációból kiderült, hogy amikor Eszter a csecsemőjét a mellkasára helyezte, korábbi pánikbetegségéhez hasonló testi érzeteket tapasztalt (például fulladásérzés, mellkasi szorító érzés), aminek nem volt tudatában, csak annak, hogy valami veszélyeztető dolog történhet. Úgy érezte, nem tudja befolyásolni a helyzetet, a helyzetet veszélyesnek címkézte. Ezért a problémafókuszú konceptualizáció során elsődleges cél volt egy reálisabb hely- zetértelmezés és a kontrollélményének kialakítása (1. táblázat).

A gondolatnaplóból látszik, hogy Eszter a pánikrohamok kapcsán megélt kontrollvesztés élményével szemben képes volt annak felismerésére, hogy szoptatáskor ő irányítja a helyzetet: „Vannak hasonlóságok a két élményben, de a jelenlegi helyzetet tudom irányitani." A negatív automatikus gondolatok hosszú láncolatát, a tépelődés által létrehozott önrontó kört a 2. ábra szemlélteti, mely egészen súlyos szorongásos állapothoz vezetett.

A szorongás csökkentése érdekében a fenti intervenciókon túl viselkedéses technikákat is alkalmaztunk. A rövid progresszív relaxáció és a 8 ütemü légzés technikája segítette a pácienst, hogy a szorongást keltő helyzetben is újra érezze a teste feletti kontrollt. A következő viselkedésterápiás módszer a szisztematikus deszenzitizálás volt, melynek során a páciens fokozatosan, egyre hoszszabb ideig találkozott a félelemkeltő helyzettel (a jelen esetben a szoptatás helyzetével). Eszterrel folyamatosan növeltük azt az időt, amelyet a csecsemő az ölében, majd a mellkasán szoptatva töltött. Az intervenciót a szoptatással, a kötődéssel és a normatív krízissel kapcsolatos pszichoedukáció kísérte. Végül a relapsusprevenció érdekében a hazamenetelhez kapcsolódó félelmeket, a lehetséges nehézségeket problémamegoldó technika segítségével dolgoztuk fel (2. táblázat). Ezzel az volt a célunk, hogy a páciens megértse: minden helyzetre van valamilyen adaptív megoldás, még akkor is, ha nem tökéletes.

Kiváltó szituáció: az édesanya a mellkasára teszi a csecsemőt

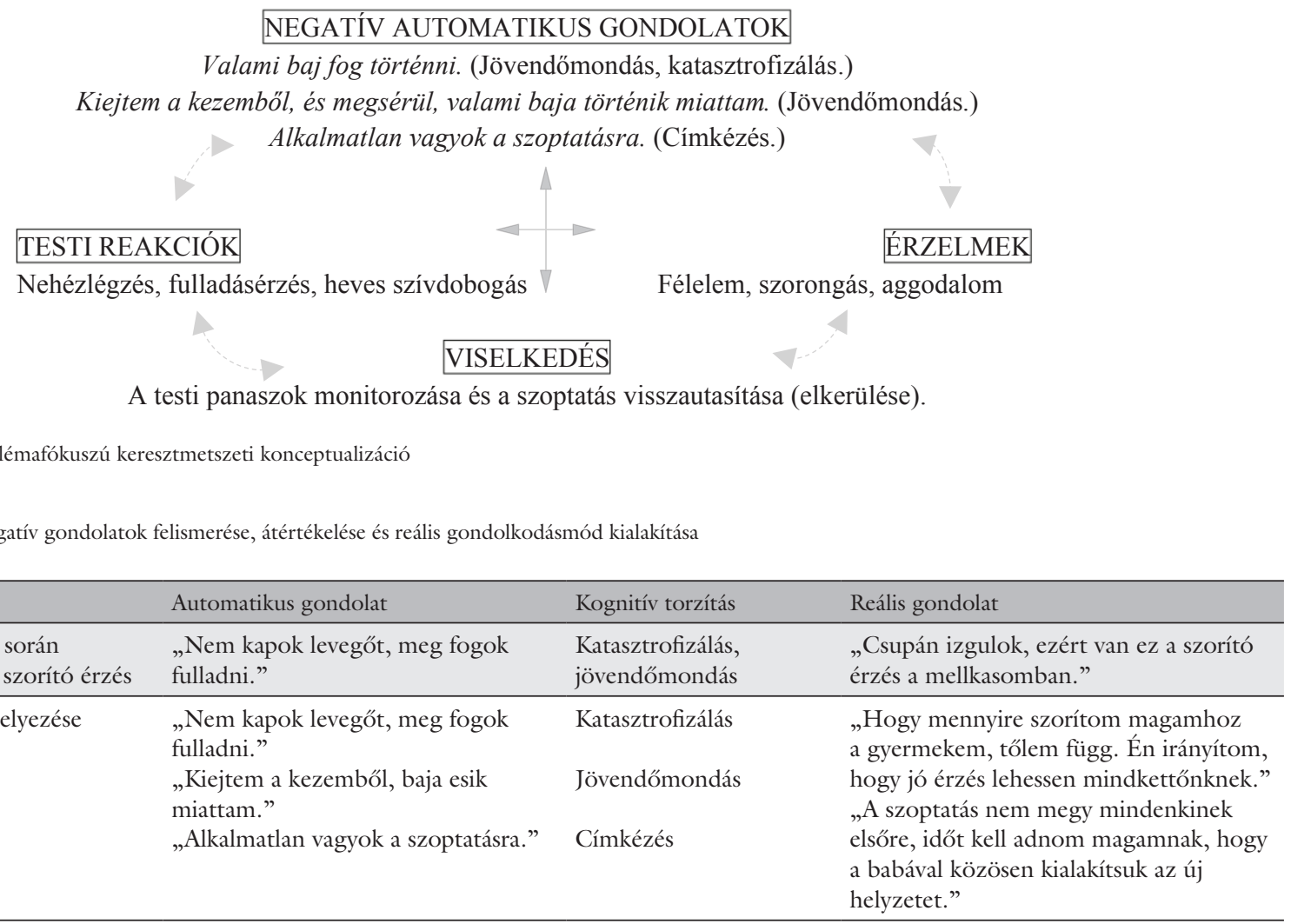




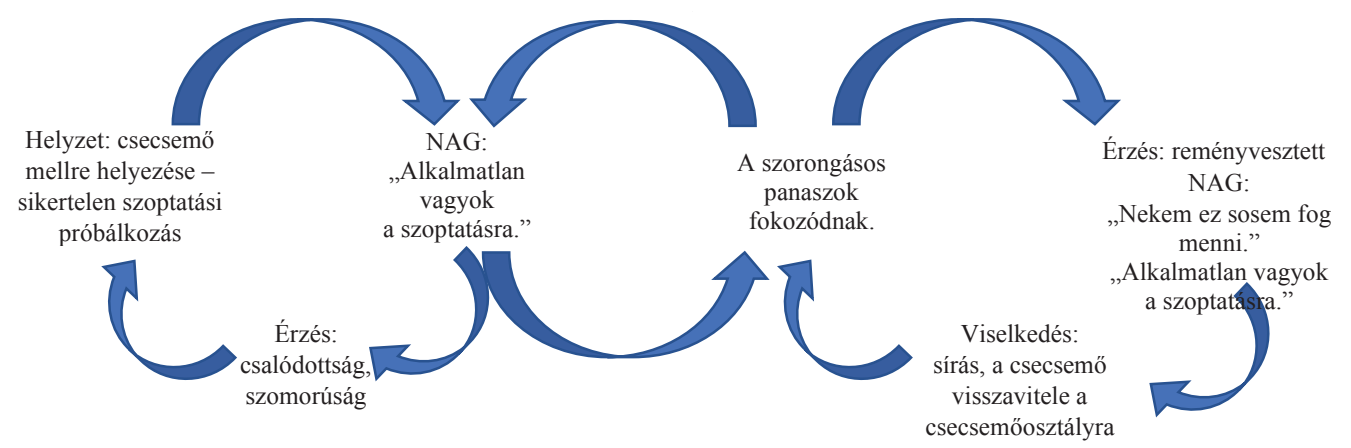

2. ábra

$\mid \begin{aligned} & \text { A tépelődés folyamata: a téves helyzetértelmezés által létrehozott önrontó kör } \\ & \text { NAG = negatív automatikus gondolat }\end{aligned}$

Eredmények: Az alacsony intenzitású kognitív viselkedésterápiás intervenciók hatására a páciens szorongása már négy alkalom után jelentősen csökkent. Eszter elkezdte szoptatni gyermekét, a szoptatással kapcsolatos szorongásai, a jövővel kapcsolatos aggodalmai csökkentek, reálisabbá vált a helyzetértékelése, kontrollélménye erősödött. A kezelőteam visszajelzése alapján is érzékelhető volt a változás az anya-csecsemő kapcsolatban, emittálni lehetett őket.

Záró pszichodiagnosztika: A kérdőívek eredményei is igazolták a LIPI-k hatékonyságát, a páciens hangulata jelentősen javult, szorongása kimutathatóan csökkent (3. táblázat).

\section{2. táblázat |A problémamegoldás lépései}

\section{Lépés: A probléma megfogalmazása}

2. Lépés: A beteg céljainak Terapeuta: Attól tart hogy amennyiben és/vagy érzéseinek megfogalmazása visszatükrözés formájában

3. Lépés: A legfontosabb Minél előbb beinduljon a tejtermelés. célok kitüzése

\begin{tabular}{ll}
\hline 4. Lépés: Ötletbörze & Megfogadom a csecsemős nővérek és \\
& a laktációs tanácsadó javaslatait, és \\
& alkalmazom azokat; nem adom fel \\
& a szoptatást, amikor kétségbe esem; \\
& egészségesen étkezem; figyelem \\
& a gyermekem jelzését; kevesebbet \\
& aggodalmaskodom.
\end{tabular}

5. Lépés: A páciens által a Megpróbálok kevesebbet rágódni, legjobbnak tartott ötlet aggodalmaskodni. kiválasztása
6. Lépés: A megoldás megvalósítása

Alkalmazom a tanult technikákat. Amikor kezdek kétségbe esni, megpihenek, majd újra folytatom a szoptatást. Olvasok, zenét hallgatok, alkalmazom a relaxációt. Megpróbálom elhalasztani a rágódást.

7. Lépés: Az eredmények Jelentősen csökkent a szorongás szintje, áttekintése

\begin{tabular}{l|ll} 
3. táblázat & $\begin{array}{l}\text { Minőségi esetvezetés - a standardizált kérdő́iveken mért ered- } \\
\text { mények }\end{array}$ \\
\hline Kérdő́iv & $\begin{array}{l}\text { A terápia elején } \\
\text { (pontszám) }\end{array}$ & $\begin{array}{l}\text { A terápia végén } \\
\text { (pontszám) }\end{array}$ \\
\hline $\begin{array}{l}\text { Beck Depresszió Kérdőív } \\
\text { (BDI) }\end{array}$ & $\begin{array}{l}18 \text { (enyhe } \\
\text { depressziós állapot) }\end{array}$ & 7 (normál) \\
$\begin{array}{l}\text { Reménytelenség Skála (RS) } \\
\text { Spielberger Állapotszorongás }\end{array}$ & $\begin{array}{l}60 \text { (fokozott } \\
\text { szorongás) }\end{array}$ & 2 (normál) \\
Kérdóív (STAI-S) & 43 (átlagos) \\
\hline
\end{tabular}

\section{Megbeszélés}

Esettanulmányunkban egy 34 éves, szorongásos panaszokkal küzdő primipara esetén keresztül mutattuk be a klinikai szakpszichológus által nagy hatékonysággal alkalmazható, alacsony intenzitású kognitív viselkedésterápiás intervenciók szülészet-nőgyógyászati osztályon való alkalmazhatóságát. A postpartum szorongásos zavarok kezelésében a nemzetközi irányelvek [22] szerint az alacsony intenzitású kognitív viselkedésterápia az elsődlegesen választandó, bizonyítottan hatékony kezelési mód.

Általános klinikai tapasztalat, hogy a szülés után közvetlenül csökken a szorongás, a nők kb. 20\%-a azonban továbbra is fokozott szorongásos panaszokról számol be [27]. Tekintettel arra, hogy a korai postpartum időszakban tapasztalt szorongás jelentősen előre jelzi a késői postpartum szorongásos zavarnak, valamint a depressziónak az előfordulását, kiemelkedő jelentőséggel bír a szülés utáni közvetlen szúrés, valamint szükség esetén a korai pszichológiai intervenció. Az eredmények, ahogy azt esetismertetésünk is példázza, alátámasztják az alacsony intenzitású kognitív viselkedésterápiás intervenciók létjogosultságát a postpartum szorongásos zavarok kezelésében. Az esetismertetésből jól látható, hogy mindössze négy ülés alatt jelentősen oldódtak a páciens szorongásos panaszai az alkalmazott alacsony intenzitású kognitív viselkedésterápiás intervencióknak köszönhetően. A szorongásos állapot normalizálása, konceptualizálása, a negatív gondolatok felismerése, a korábbi pánikbetegség és a jelenlegi szorongásos állapot hasonlóságainak és különbségeinek tudatosítása, valamint a rövid problémamegoldó technikák lehetővé tették a súlyo- 
sabb szorongásos állapot prevencióját. A terápia sikeréhez az is hozzájárult, hogy a páciens nagyon motivált volt, megfelelő önreflexiós és önverbalizációs készséggel rendelkezett. A páciens negatív automatikus gondolatai könnyen hozzáférhetők voltak, elfogadta a kognitív pszichoterápiás módszereket és magyarázó elvet, és az is világosan látható volt számára, hogyan illeszkedik mindez a saját problémáinak megoldásához. A LIPI-k központi eleme a korábbi pánikbetegséggel való hasonlóság felismerése és korrigálása volt (mellkasi nyomás érzése akkor és most, a szoptatáskor). A tépelődés megjelenése sérülékenységet jelentett egy későbbi kényszeres tünetképződéshez vagy affektív kórkép kialakulására, azonban az alkalmazott technikák segítségével aktuálisan le lehetett állítani a tépelődés folyamatát, így megelőzhető volt egy komolyabb pszichiátriai zavar kialakulása. A reális helyzetértékelések bevezetésével párhuzamosan csökkent a páciens szorongása, elkezdte szoptatni csecsemőjét, ezáltal pedig fokozódott az anyai kompetencia érzése ebben a nagyon szenzitív periódusban.

\section{Kitekintés}

Tanulmányunkban arra törekedtünk, hogy bemutassuk a szomatikus ellátásban, ezen belül a szülészeti osztályon alkalmazható, alacsony intenzitású kognitív viselkedésterápiát. A módszer a modern klinikai szakpszichológia eszköztárának rendkívüli területe, mert jól adaptálható az osztályos ellátás feltételeihez, eredményesen és hatékonyan kivitelezhető a rövid idejü hospitalizáció ellenére is. Az alacsony intenzitás előnye, hogy a pszichoterápiás intervenciók jól illeszthetők az osztályos ellátás feltételeihez, kereteihez és a páciens aktuális pszichés terhelhetőségéhez, így az osztályos kereteken átívelve folytonos tud maradni, megvalósítható a korai és késői postpartum időszakban is (például e-mail, skype, telefon, önsegítő technikák, applikációk segítségével). Végül, de nem utolsósorban a LIPI-k alkalmazása hatalmas előrelépést jelent a pszichés zavarok megelőzésében, ezáltal is tehermentesítve a pszichiátriai szakellátást. Öszintén reméljük, hogy tanulmányunkkal hozzájárulunk a hazai betegellátás korszerüsítéséhez.

Anyagi támogatás: A kutatást az Innovációs és Technológiai Minisztérium Felsőoktatási Intézményi Kiválósági Programja finanszírozta a Semmelweis Egyetem Neurológia tématerület programja keretében.

Szerzői munkamegosztás: Z.-G. Á.: Terápiás munka, irodalomkutatás, a cikk megírása. P.-F. D.: A közlemény megírásának ötlete, struktúrájának kialakítása, kritikai átdolgozása, valamint folyamatos szakmai szupervízió. A cikk végleges változatát mindkét szerző elolvasta és jóváhagyta.

Érdekeltségek: A szerzőknek nincsenek érdekeltségeik.

\section{Irodalom}

[1] Hajduska M. Crisis psychology. [Krízislélektan.] ELTE Eötvös Kiadó, Budapest, 2015. [Hungarian]

[2] Roberts L, Davis GK, Homer CS. Depression, anxiety, and posttraumatic stress disorder following a hypertensive disorder of pregnancy: a narrative literature review. Front Cardiovasc Med. 2019; 6: 147.

[3] Rees S, Channon S, Waters CS. The impact of maternal prenatal and postnatal anxiety on children's emotional problems: a systematic review. Eur Child Adolesc Psychiatry 2019; 28: 257280.

[4] Fawcett EJ, Fairbrother N, Cox ML, et al. The prevalence of anxiety disorders during pregnancy and the postpartum period: a multivariate Bayesian meta-analysis. J Clin Psychiatry 2019; 80: $18 \mathrm{r} 12527$.

[5] Dennis CL, Coghlan M, Vigod S. Can we identify mothers atrisk for postpartum anxiety in the immediate postpartum period using the state-trait anxiety inventory? J Affect Disord. 2013; 150: 1217-1220.

[6] Farr SL, Dietz PM, O'Hara MW, et al. Postpartum anxiety and comorbid depression in a population-based sample of women. J Womens Health 2014; 23: 120-128.

[7] Aktan NM. Social support and anxiety in pregnant and postpartum women: a secondary analysis. Clin Nurs Res. 2012; 21 : 183-194.

[8] Fatoye FO, Oladimeji BY, Adeyemi AB. Difficult delivery and some related selected factors as predictors of early postpartum psychological symptoms among Nigerian women. J Psychosom Res. 2006; 60: 299-301.

[9] Paul IM, Downs DS, Schaefer EW, et al. Postpartum anxiety and maternal-infant health outcomes. Pediatrics 2013; 131: e1218el224.

[10] Field T. Postpartum anxiety prevalence, predictors and effects on child development: a review. J Psychiatr Psychiatr Disord. 2017; 1: 86-102.

[11] DiPietro JA, Costigan KA, Gurewitsch ED. Fetal response to induced maternal stress. Early Hum Dev. 2003; 74: 125-138.

[12] Monk C, Myers MM, Sloan RP, et al. Effects of women's stresselicited physiological activity and chronic anxiety on fetal heart rate. J Dev Behav Pediatr. 2003; 24: 32-38.

[13] Alderdice F, Lynn F, Lobel M. A review and psychometric evaluation of pregnancy-specific stress measures. J Psychosom Obstet Gynecol. 2012; 33: 62-77.

[14] Coussons-Read ME. Effects of prenatal stress on pregnancy and human development: mechanisms and pathways. Obstet Med. 2013; 6: 52-57.

[15] Berthelon M, Kruger D, Sanchez R. Maternal stress during pregnancy and early childhood development. IZA DP No. 11452. April 2018; pp. 1-42.

[16] Hámori E. Disorders of early contact. Psychoanalysis, attachment theory and infant research in understanding early relationship pathologies. [A korai kapcsolat zavarai. Pszichoanalízis, kötődéselmélet és csecsemókutatás a korai kapcsolati patológiák megértésében.] Oriold és Társai Kiadó, Budapest, 2016. [Hungarian] 
[17] Alipour Z, Lamyian M, Hajizadeh E. Anxiety and fear of childbirth as predictors of postnatal depression in nulliparous women. Women Birth 2012; 25: e37-e43.

[18] Sutter-Dallay AL, Giaconne-Marcesche V, Glatigny-Dallay E, et al. Women with anxiety disorders during pregnancy are at increased risk of intense postnatal depressive symptoms: a prospective survey of the MATQUID cohort. Eur Psychiatry 2004; 19: $459-463$.

[19] Reck C, Noe D, Gerstenlauer J, et al. Effects of postpartum anxiety disorders and depression on maternal self-confidence. Infant Behav Dev. 2012; 35: 264-272.

[20] Ali NS, Mahmud S, Khan A, et al. Impact of postpartum anxiety and depression on child's mental development from two periurban communities of Karachi, Pakistan: a quasi-experimental study. BMC Psychiatry 2013; 13: 274.

[21] Miklósi M. The role of cognitive emotion regulation in stress responses. Doctoral dissertation. [A kognitív érzelem-szabályozás szerepe a stresszre adott reakciókban. Doktori értekezés.] Semmelweis Egyetem Mentális Egészségtudományok Doktori Iskola, Budapest, 2015. [Hungarian]

[22] National Institute for Health and Care Excellence. Interventions for anxiety disorders. NICE, London, 2014. Available from: https://www.nice.org.uk/guidance/cg192/chapter/1Recommendations\#treating-specific-mental-health-problemsin-pregnancy-and-the-postnatal-period [accessed: May 10, 2020].

[23] Purebl Gy. Low intensity psychosocial interventions - quick and psychological support. [Alacsony intenzitású pszichológiai inter- venciók - pszichológiai támogatás gyorsan, egyszerúen.] eConsilium, 2017. júl. 19. Available from: http://econsilium.hu/ tag/alacsony-intenzitasu-pszichologiai-intervencio/ [accessed: May 10, 2020]. [Hungarian]

[24] Vincze Á, Perczel-Forintos D. Cognitive behavioral therapy interventions in chronic physical illness. In: Perczel-Forintos D, Mórotz K. (eds.) Cognitive behavioral therapy. Kognitív viselkedésterápiás intervenciók krónikus testi betegségekben. In: Perczel-Forintos D, Mórotz K. (szerk.) Kognitív viselkedésterápia.] Medicina Könyvkiadó, Budapest, 2019; pp. 299-321. [Hungarian]

[25] Bennett-Levy J, Richards D, Farrand P, et al. Oxford guide to low intensity CBT interventions. Oxford University Press Inc., New York, NY, 2010.

[26] Antal-Uram D, Harsányi L, Perczel-Forintos D. Low-intensity, evidence-based cognitive-behavioral therapy of a patient with Crohn's disease. [Az alacsony intenzitású, bizonyítottan hatékony kognitív viselkedésterápia Crohn-betegségben.] Orv Hetil. 2018; 152: 363-369. [Hungarian]

[27] Radoš SN, Tadinac M, Herman R. Anxiety during pregnancy and postpartum: course, predictors and comorbidity with postpartum depression. Acta Clin Croat. 2018; 57: 39-51.

(Perczel-Forintos Dóra dr., Budapest, Üllői út 25., 1091

e-mail: perczel-forintos.dora@med.semmelweis-univ.hu)

\section{"Deliberando discitur sapientia." (Bölcsességre a megfontolás tanít.)}

A cikk a Creative Commons Attribution 4.0 International License (https://creativecommons.org/licenses/by/4.0/) feltételei szerint publikált Open Access közlemény, melynek szellemében a cikk bármilyen médiumban szabadon felhasználható, megosztható és újraközölhető, feltéve, hogy az eredeti szerző és a közlés helye, illetve a CC License linkje és az esetlegesen végrehajtott módositások feltüntetésre kerülnek. (SID_1) 